American Journal of Agricultural and Biological Sciences 4 (2): 105-109, 2009

ISSN 1557-4989

(C) 2009 Science Publications

\title{
Reorganization of Agricultural Extension toward Green Agriculture
}

\author{
Mohammad S. Allahyari \\ College of Agriculture, Islamic Azad University, Rasht Branch, Rasht, Iran
}

\begin{abstract}
Problem statement: Considering unsustainable agricultural conditions of Iran and organizational recession and inability of current extension organization to achieve sustainability, it seems that extension systems require a new organizational structure to achieve sustainability objectives. The purpose of the present study was to identify the most appropriate characteristics for extension organization toward green agriculture in Iran context. Approach: To fulfill this objective, a sample of 120 respondents was selected through simple random sampling technique. A survey study was applied as a methodology of research. A mailed questionnaire was used to collect the data. The response rate of questionnaire was $65.83 \%(\mathrm{~N}=79)$. Appropriate descriptive statistics such as mean scores, standard deviations and variation ratio were used. Results: Extension experts believed that among important organizational characteristics of extension system for supporting green agriculture collaboration among research, extension, education organizations, farmers' associations, NGOs, rural credit agencies, transportation companies, considering local groups and learning organization had very high importance for supporting green agriculture. According to factor analysis, the implications for extension organization were categorized into two groups consisting: (1) Holistic organizations (2) Participatory organizations that those factors explained $67.54 \%$ of the total variance of the research variables. Conclusion: Identifying suitable extension mechanisms had important role for developing extension system. Therefore, identifying extension organizational characteristics for supporting green agriculture of Iran is one of the major approaches needs to be carefully thought and accurately implemented for the extension system development.
\end{abstract}

Key words: Extension organization, green agriculture, sustainability, Iran

\section{INTRODUCTION}

The agricultural extension system is one of the primary vehicles for diffusing technologies and therefore clearly has an important role to play in the development process $^{[1,2]}$. By shifting development paradigm, experiences in agricultural extension and development have indicated that traditional approaches will need to transform in order to move toward sustainability ${ }^{[3]}$. Within new paradigm, the institutional dimension of the transformation to a more sustainable society is rapidly emerging as a crucial area of interest. Existing organizational frameworks mitigate against the emergence of the green agricultural practices and new networks and institutions are rapidly emerging ${ }^{[4-6]}$. One of the new challenges for extension organizations is to become learning organization ${ }^{[7-10]}$. Learning organizations are organizations that continually expand their capacity to create their future. These organizations require five disciplines including personal mastery, awareness of mental models, building shared vision, team learning and systems thinking ${ }^{[11]}$. These types of organizations will have to promote experimentation, promote connectivity and group work based on roles rather than disciplines and develop monitoring selfevaluation systems to improve learning and awareness $^{[8]}$. Public models for provisioning of agricultural extension are considered to have fallen into disrepute in many countries due to poor progress in achieving policy aims such as export, food security, sustainability and social well-being. Now, Extension systems should be much broader and more diverse, including public and private sector and civil society institutions that provide a broad range of services (advisory, technology transfer, training, promotional and information) on a wide variety of subjects (such as agriculture, marketing, social organization, health and

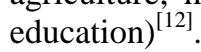

According to $\mathrm{Zijp}^{[13]}$ in order to meet farmers' needs he proposed some changes, which will lead to more pluralism in the services offered and the organizations providing these services (Table 1).

Pluralism as a key element of new paradigm is emergence of multiplicity of actors providing services, either autonomously in response to farmer demand or facilitated by government policy measures ${ }^{[14]}$. 
Table 1: Shifting extension organizations toward pluralism

\begin{tabular}{|c|c|}
\hline From & To \\
\hline $\begin{array}{l}\text { Looking at extension as national } \\
\text { government service }\end{array}$ & $\begin{array}{l}\text { Seeing extension as a set of functions, to be performed by a variety of players, at } \\
\text { different levels }\end{array}$ \\
\hline $\begin{array}{l}\text { Looking at extension to transfer } \\
\text { technologies }\end{array}$ & $\begin{array}{l}\text { Seeing a wider mandate for extension, that also includes farmer mobilization, organization } \\
\text { and education }\end{array}$ \\
\hline $\begin{array}{l}\text { Looking at extension as a distinct, } \\
\text { separate institution }\end{array}$ & $\begin{array}{l}\text { Seeing a coherent, comprehensive knowledge system for the generation, transfer and } \\
\text { uptake of knowledge and technology, that includes the farmers, research, extension and } \\
\text { education }\end{array}$ \\
\hline $\begin{array}{l}\text { Using a linear, sequential and one } \\
\text {-directional model of technology transfer }\end{array}$ & $\begin{array}{l}\text { A more realistic, cyclical and dynamic model of information exchange and knowledge } \\
\text { dissemination whereby farmers, researchers, educators and extensionists are all engaged } \\
\text { in the generation of new knowledge and in its transfer and in its use }\end{array}$ \\
\hline $\begin{array}{l}\text { Designing projects from a teaching } \\
\text { perspective and budgeting for teaching efforts }\end{array}$ & Allowing projects to develop a learning mode, engaging all major stakeholders \\
\hline $\begin{array}{l}\text { Paying lip service to the potential of } \\
\text { information technology for rural development }\end{array}$ & $\begin{array}{l}\text { Taking some risks by including experimental information technologies in projects to link } \\
\text { research institutes, extension managers, farmer organizations and others to each other and } \\
\text { to the rest of the world }\end{array}$ \\
\hline
\end{tabular}

Adapted from Zijp ${ }^{[13]}$

Pluralism focuses on the interface of farmers, extensionists, input suppliers and a host of other actors in rural development ${ }^{[6]}$. Decentralization is one of the most important features in agricultural extension restructuring toward green agriculture. According to Rivera $^{[15]}$ decentralization has been defined as "the transfer of planning, decision making or management functions from the central government and its agencies to field organizations, subordinate units of government, semi-autonomous public corporations, area-wide or regional development organizations, specialized functional authorities or non-governmental organizations". Decentralization aims at a better tuning of public services to the preferences and demands of local people ${ }^{[16]}$.

The purpose of the present study was to identify the most appropriate features for extension organization toward sustainability in Iran context.

\section{MATERIALS AND METHODS}

A questionnaire was mailed out to 120 of faculty members of agricultural extension education, extension head in provinces and extension specialists of deputy of agricultural extension and farming system in the ministry of agriculture (Jihad-e-Keshavarzi) in Iran. Seventy-nine usable questionnaires were returned, representing a $65.83 \%$ return rate. An early versus late respondent comparison was made to determine if no responses was a threat to validity of the study ${ }^{[17]}$. Using this procedure, no statistically significant differences between the groups were found. Therefore, findings from this study are assumed generalizable to the population from which it was drawn. The survey was divided into two sections to gather data on personal characteristics of extension specialists and importance rate of extension organization characteristics for supporting green agriculture on a five point Likert-type scale: 1 = Very low, $2=$ Low, $3=$ Moderate, $4=$ High, $5=$ Very high. To ensure its content and face validity, the research instrument was reviewed several times by the research group and then implemented in a pilot test to measure its reliability. Questionnaire reliability was estimated by calculating Cronbach's alpha. Reliability of the overall instrument was estimated at 0.92. It meant that index had high reliability. The data were collected between October 2006 and March 2007. After gathering and encoding information from the questionnaires, data was obtained for analysis. Data collected were analyzed using the Statistical Package for the Social Sciences (SPSS, 14). Beside descriptive statistics (mean, standard deviation and variation ratio), factor analysis was employed for detailed analysis.

\section{RESULTS AND DISCUSSION}

The demographic characteristics of the respondents showed that the ages of the respondents ranged from 25-63. The mean age was $38(\mathrm{SD}=8.87, \mathrm{~N}=79)$. About $39.2 \%(n=31)$ of the respondents belonged to the age group ranging from 31-40 years old. Most of the respondents in the study were male (93.7) and only 5 persons $(6.3 \%)$ were female. The respondents' years of experience ranged from 2-30. The mean years served in extension were 12.4 ( $\mathrm{SD}=8.75)$. Nearly one-third of agricultural extension professionals $(29.1 \%)$ had served in extension for 1-5 years. $29.1 \%$ of extension specialists had a doctoral degree in agricultural extension and education discipline and sixty- tow percent $(n=49)$ of respondents were a masters degree holders. only $8.9 \%$ of extension specialists had a bachelor's degree $(n=7)$. About $35.4 \%$ of respondents $(\mathrm{n}=28)$ were faculty members and $15.25 \%(\mathrm{n}=12)$ had a managerial position. Remain were extension 
experts (49.35). $35.4 \%$ of respondents worked at universities, $27.8 \%(\mathrm{n}=22)$ worked at agriculture ministry. About $29.1 \%(n=23)$ of extension specialists worked in agricultural extension services at province level and remain worked at county level $(6.3 \%)$.

In section two, agricultural extension experts were asked to mention importance rate of extension organization characteristics for supporting green agriculture on a five point Likert-type scale: $1=$ Very low, 2 = Low, 3 = Moderate, $4=$ High, $5=$ Very high . The replies prioritized according to means and Variation Ratios (VR). Because VR depicts the variation of perceptions, lower VR, i.e., lower variation of the respondents' perceptions (more homogeneous), for same mean, placed on higher rank. Ranking based on the perceptions of extension experts indicated that the five most important extension organization characteristics for supporting green agriculture were: Collaboration among research, extension, education organizations, farmers' associations, NGOs, rural credit agencies, transportation companies $(\mathrm{M}=4.56 ; \mathrm{VR}=0.342)$, Considering local groups $(\mathrm{M}=4.60 ; \mathrm{VR}=0.385)$, Learning organization $(\mathrm{M}=4.53 ; \mathrm{VR}=0.391)$, Pluralism $(\mathrm{M}=4.45$; $\mathrm{VR}=0.397)$ and decentralization $(\mathrm{M}=4.38 ; \mathrm{VR}=0.468)($ Table 2$)$.

Based on the results, most effective characteristic of extension organization for supporting GA was Collaboration among research, extension, education organizations, farmers' associations, NGOs, rural credit agencies, transportation companies. According to Cho and Boland $^{[10]}$ in promoting development of agricultural extension services, the importance of institutional linkage between the rural community and the development agents should be considered. With this in mind, a framework that can serve as linkage system between the government organizations, nongovernmental organizations and farmers' associations is proposed. The second priority for extension organizational characteristics toward green agriculture was "considering local groups". A necessary condition for sustainable agriculture is that large number of farmer must be motivated to use, their resource in a coordinated manner. Thus, the success of sustainable agriculture depends on motivations, skills, knowledge and action taken by groups or communities as a whole ${ }^{[8,18,19]}$.

Exploratory Principal Component Analysis (PCA) was conducted to summarize the variables of the research to a smaller quantity and to determine the most appropriate features for extension organization toward sustainability and the obtained factors were subjected to VARIMAX rotation. PCA is a form of factor analysis, which first looks for a linear combination of variables that extracts maximum variance from variables and then identifies a second linear combination to explain the remaining variance, leading to orthogonal, or uncorrelated, factors $^{[20]}$. The value of the Kaiser-MeyerOlkin measure of sampling adequacy (KMO) was 0.877. Nelson and Thompson ${ }^{[21]}$ reported that KMO values of 0.6 and above are required for good factor analysis. Using the eigenvalue greater than one rule, the PCA suggested the presence of two factors, which accounted for $67.54 \%$ variance in scores. The eigenvalues and percentage of explained variances are showed in Table 3. The two factors extracted and named in this study follow:

- Holistic organizations and

- Participatory organizations

The first implication for extension organizations toward green agriculture was called the "Holistic organizations". This factor had the most eigenvalue (3.48). Also this factor explained $34.85 \%$ of the total variances of the variables. This implication consisted of five items including "Considering contingency management", Collaboration among research, extension, education organizations, farmers' associations, NGOs, rural credit agencies, transportation companies", "Considering systemic management", "Pluralism" and "Decentralization". The second implication was called the "Participatory Organizations ". This factor that its eigenvalue was 3.27 explained $32.69 \%$ of the total variances of the variables.

Table 2: Respondents' perceptions towards necessary characteristics for extension organization to accomplish green agriculture

\begin{tabular}{|c|c|c|c|c|}
\hline Rank & Importance of organizational characteristics for supporting GA & M & SD & VR \\
\hline 1 & $\begin{array}{l}\text { Collaboration among research, extension, education organizations, } \\
\text { farmers' associations, NGOs, rural credit agencies, transportation companies }\end{array}$ & 4.56 & 0.75 & 0.342 \\
\hline 2 & Considering local groups & 4.60 & 0.54 & 0.385 \\
\hline 3 & Learning organization & 4.53 & 0.50 & 0.391 \\
\hline 4 & Pluralism & 4.45 & 0.85 & 0.397 \\
\hline 5 & Decentralization & 4.38 & 0.65 & 0.468 \\
\hline 6 & Considering systemic management & 4.39 & 0.77 & 0.474 \\
\hline 7 & Using leadership skills & 4.30 & 0.72 & 0.494 \\
\hline 8 & Flexibility of roles, tasks and commitments & 4.39 & 0.77 & 0.519 \\
\hline 9 & Considering contingency management & 4.25 & 0.88 & 0.519 \\
\hline 10 & Horizontal communication & 4.26 & 0.70 & 0.544 \\
\hline
\end{tabular}


Table 3: Results of factor analysis for extension organization characteristics toward green agriculture

\begin{tabular}{lll}
\hline & \multicolumn{2}{l}{ Factor } \\
Necessary attributes for extension & ------- \\
organization toward green agriculture & 1 & 2 \\
\hline Holistic organizations: & 0.825 & \\
$\begin{array}{l}\text { Considering contingency management } \\
\text { Collaboration among research, extension, education } \\
\text { organizations, farmers' associations, NGOs, rural }\end{array}$ & 0.794 & \\
credit agencies, transportation companies & & \\
Considering systemic management & 0.778 & \\
Pluralism & 0.734 & \\
$\begin{array}{l}\text { Decentralization } \\
\text { Participatory organizations: }\end{array}$ & 0.716 & \\
Considering local groups & & \\
Flexibility of roles, tasks and commitments & & 0.826 \\
Horizontal communication & & 0.747 \\
Learning organization & & 0.740 \\
Using leadership skills & & 0.681 \\
Eigen value & 3.480 & 3.270 \\
Percent variance & 34.85 & 32.69 \\
Cumulative percentage & 34.85 & 67.54 \\
\hline
\end{tabular}

This was similar to Ommani et al. ${ }^{[8]}$ findings on extension methods and organizational characteristics for supporting Sustainable Water Resource Management (SWRM) in agriculture of Iran. They reported considering local groups and participatory management as the most effective characteristic of extension organization for supporting SWRM.

\section{CONCLUSION}

Several studies in Iran showed that, although extension services has played a positive role in agricultural development of $\operatorname{Iran}^{[22]}$, but there are difficulties, barriers, misunderstandings and weaknesses in the transfer of new technology and information to farmers. Lacking the suitable extension organizational characteristics has been a barrier for transfer of appropriate new technology to farmers ${ }^{[8]}$. Fundamental reforms in extension, moving away from hierarchical (top-down) transfer of information or advice, towards a 'mutual learning' process can help better design of relevant research, enhanced uptake of technology and more desirable or less disruptive impacts on development ${ }^{[23]}$. This study revealed that Iran's extension system does not pay enough attention to necessity characteristics of extension organizations to accomplish green agriculture and these attributes are not favorable situation. These conditions necessitate reorganizing of extension institutions to accomplish sustainability. The findings of study show that to accomplish green agriculture, we must give attention to two groups of characteristics: (1) Holistic organizations and (2) Participatory organizations. Identifying suitable extension mechanisms have important role for developing extension system. Therefore, identifying extension organizational characteristics for supporting green agriculture of Iran is the one of the major approaches needs to be carefully thought and accurately implemented for the extension system development.

\section{REFERENCES}

1. Umali, D.D., 1997. Public and private agricultural extension: Partners or rivals? World Bank Res. Observer, $\quad$ 12: 203-224. http://wbro.oxfordjournals.org/cgi/content/abstract/ 12/2/203

2. Kidd, A.D., J.P.A. Lamers, P.P. Ficarelli and V. Hoffmann, 2000. Privatizing agricultural extension: Caveat emptor. J. Rural Stud., 16: 95-102. DOI: 10.1016/S0743-0167(99)00040-6

3. Toness, A.S., 2001. The potential of Participatory Rural Appraisal (PRA) approaches and methods for agricultural extension and development in 21st century. J. Int. Agric. Extens. Educ., 8: 25-37. http://www.aiaee.org/archive/Vol-8.1.pdf

4. Roling, N.G. and J. Jiggins, 1998. The Ecological Knowledge System. In: Facilitating Sustainable Agriculture, Rolling, N.G. and M.A.E. Wagemakers, (Eds.). Cambridge, Cambridge University press, ISBN: 0-521-79481-1, pp: 318.

5. Allahyari, M.S., 2008. Extension mechanisms to support sustainable agriculture in Iran context. Am. J. Agric. Biol. Sci., 3: 647-655. http://www.scipub.org/fulltext/AJAB/AJAB34647655.pdf

6. Allahyari, M.S. and M. Chizari, 2008. Supportive organizations regarding environmentally sound agriculture in Iran. Green Farm. J., 1: 1-5. http://allahyarister.googlepages.com/home

7. Leeuwis, C. and A. Vanden Ben, 2004. Communication for Rural Innovation: Rethinking Agricultural Extension. 2nd Edn., Blackwell, Iowa, USA., ISBN: 10: 063205249X, pp: 424.

8. Ommani, A.R., M. Chizari, C. Salmanzadeh and J.F. Hosseini, 2008. Extension methods and organizational characteristics for supporting sustainable water resource management in agriculture of Iran. J. Applied Sci., 9: 567-572. DOI: $10.3923 /$ jas.2009.567.572

9. Fulton, A. D. Fulton, T. Tabart, P. Ball, S. Champion, J. Weatherley and D. Heinjus, 2003. Agricultural Extension, Learning and Change. 1st Edn., RIRDC Publication, Kingston, ISBN: 0642586004. 
10. Cho, K.M. and H. Boland, 2004. Education and extension for multi-functional agriculture: Extension concepts for sustainable agricultural development in Myanmar. Proceedings of 20th Annual Conference on AIAEE, May 23-29, Dublin, Ireland, pp: 531-537. http://www.aiaee.org/2004/Accepted/069.pdf

11. Fisk, J.W., O.B., Hesterman and T.L Thoburn, 1998. Integrated Farming Systems: A Sustainable Agriculture Learning Community in the USA. In: Facilitating Sustainable Agriculture, Roling, N.G. and M.A.E. Wagemakers (Eds.). Cambridge University Press, Cambridge, UK., ISBN: 0-52179481-1, pp: 215-232.

12. World Bank, 2005. Agriculture Investment Sourcebook. 1st Edn., World Bank, Washington DC., USA., ISBN: 08213-6085x, pp: 508.

13. Zijp, W., 1998. Promoting pluralism. J. Agric. Educ. Extens., 5: 1-12.

14. Ponniah, A., R. Puskur, S. Workneh and D. Hoekstra, 2008. Concepts and Practices in Agricultural Extension in Developing Countries: A Source Book. 1st Edn., International Livestock Research Institute, Addis Ababa, Ethiopia, ISBN: 92-9146217-9.

15. Rivera, W.M., 1997. Agricultural extension into the next decade. Eur. J. Agric. Edu. Extens., 4: 29-38.

16. Tossou, C.R. and M. Zinnah, 2005. Search for better institutional arrangements for agricultural extension services in a decentralized context: The republic of Benin. J. Int. Agric. Extens. Educ., 12: 43-52. http://www.aiaee.org/archive/Vol12.3.pdf

17. Lindner, J.R., T.H., Murphy and G.E. Briers, 2001. Handling non-response in social science research. J. Agric. $\quad$ Educ., 42: 43-53. http://pubs.aged.tamu.edu/jae/pdf/Vol42/42-0443.pdf
18. Roling, N. and J.N. Pretty, 1997. Extension Role in Sustainable Agricultural Development. In: Improving Agricultural Extension, Swanson, B.E., R.P. Bentz and A.J. Sotranko (Eds.). Food and Agriculture Organization, Rome, ISBN: 92-5104007-9, pp: 181-193.

19. Aghasizadeh, F. and M. Hosseini, 2004. Factors analysis and new obligations on designing organizational structure of agricultural extension in Iran. Pajouhesh Sazandegi, 64: 80-93.

20. Rehman, T., K. McKemey, C.M. Yates, R.J. Cooke, C.J. Garforth, R.B. Tranter, J.R. Park and P.T. Dorward, 2007. Identifying and understanding factors influencing the uptake of new technologies on dairy farms in SW England using the theory of reasoned action. Agric. Syst., 94: 281-293. DOI: 10.1016/j.agsy.2006.09.006

21. Nelson, S.J. and G.W. Thompson, 2005. Barriers perceived by administrators and faculty regarding the use of distance education technologies in preservice programs for secondary agricultural education teachers. J. Agric. Educ., 46: 36-48. http://pubs.aged.tamu.edu/jae/pdf/Vol46/46-04-36.pdf

22. Asadi, A., M. Akbari, H. Shabanali Fami and A. Alambaigi, 2008. An assessment of farmers willingness to pay for wheat consultant engineers project: In Iran. Am. J. Agric. Bio. Sci., 3: 706-711. http://www.scipub.org/fulltext/AJAB/AJAB34706711.pdf

23. Raina, R.S., 2003. Institutions and Organizations: Agricultural Policy, Research and Extension. In: Institutional Change in Indian Agriculture, Pal, S., P.K. Mruthyunjaya, Joshi and R. Saxena (Eds.). Chandu Press, Shakarpur, Delhi, India. 